\title{
HUBUNGAN METODE BERCERITA DENGAN KARAKTER SISWA DI MADRASAH IBTIDAIYAH NEGERI 1 PURBALINGGA
}

\author{
Siti Mangunah \\ (MIN 1 Purbalingga) \\ mangunah@min1purbalingga.sch.id
}

\begin{abstract}
ABSTRAK
Penelitian ini didasari oleh pentingnya karakter dalam mewujudkan generasi muda yang berkarakter baik. Sehubungan dengan hal tersebut, penelitian ini bertujuan untuk mengetahui hubungan metode bercerita dengan karakter siswa di MIN 1 Purbalingga. Penelitian ini menggunakan pendekatan penelitian kuantitatif. Sedangkan jenis penelitian yang digunakan pada penelitian ini yaitu penelitian quasi eksperimental design atau desain eksperimen semu. Desain eksperimen yang digunakan dalam penelitian ini adalah "pretest-posttest control group design" atau desain kelompok prates dan pasca tes yang melibatkan dua kelompok. Kategori pembelajaran dibagi menjadi dua kategori yaitu kelas eksperimen melakukan kegiatan bercerita. Sedangkan kelas kontrol tidak melakukan kegiatan bercerita. Pengumpulan data menggunakan angket atau kuesioner, didukung juga dengan teknik wawancara, observasi, dan dokumentasi. Metode analisis data dalam penelitian ini yaitu menggunakan: (1) Descriptive Statistics; (2) Test of Equality of Error Variances; dan (3) Test of BetweenSubjects Effects. Penelitian ini menghasilkan kesimpulan bahwa: Signifikansi Metode Bercerita adalah 0,000. Karena signifikansi $<0,05(0,000<0,05)$, maka Ho ditolak. Jadi, dapat disimpulkan bahwa terdapat perbedaan rata-rata nilai karakter siswa antara pembelajaran menggunakan metode bercerita dengan pembelajaran yang tidak menggunakan metode bercerita.
\end{abstract}

Kata kunci: Metode Bercerita \& Karakter Siswa.

\section{PENDAHULUAN}

Perubahan jaman merupakan tanda suatu kehidupan yang dinamis. Perubahan merupakan sesuatu yang mesti ada dalam kehidupan. Perubahan merupakan tanda suatu kehidupan. Begitu juga dalam dunia pendidikan, yang selalu berubah. Perubahan perlu diantisipasi dengan kesiapan guna mampu menghadapi setiap perubahan yang ada. Pendidikan perlu mempersiapkan siswa yang tangguh, yang tanggap terhadap perubahan serta mampu memenangkan perubahan jaman tersebut. 
Pendidikan yang berbasis karakter perlu ditekankan guna pencapaian hasil pembelajaran yang optimal. Pendidikan tidak cukup dengan penguasaan pengetahuan dan atau penguasaan banyak keterampilan. Namun, pendidikan perlu lebih berfokus pada aspek afektif. Pendidikan perlu membina karakter siswa, guna perbaikan kualitas sosial bangsa. Pembelajaran perlu dirancang guna menghasilkan lulusan yang berkarakter baik.

Jika realitanya belum demikian, maka ini adalah kesempatan yang baik untuk merubahnya. Saat ini adalah waktunya untuk memperbaiki sistem pendidikan yang lebih baik. Sumber daya manusia pendidikan harus berkualitas, yaitu profesional. Ciri profesional yaitu memiliki dan melaksanakan kometensi yang dipersyaratkan. Melalui keprofesionalan kerja tersebut, maka kualitas pendidikan dapat tercapai.

Pendidikan di sekolah harus berbenah diri dalam mewujudkan generasi muda penerus bangsa yang berkarakter baik. Penguatan pendidikan karakter perlu senantiasa dibina dan ditingkatkan kualitasnya. Melalui banyak cara, terutama metode pembelajaran, maka karakter siswa dapat dibentuk menjadi baik. Melalui pembelajaran yang berkualitas, maka tujuan pendidikan dapat tercapai secara optimal. Semua stakeholder pendidikan harus bekerjasama dan saling membantu dalam meningkatkan kualitas pendidikan.

Metode pembelajaran yang tepat dapat membantu pencapaian tujuan pembelajaran secara baik. Salah satunya melalui metode bercerita. Metode tersebut umum digunakan dalam proses pembelajaran. Metode tersebut mengandung sisi positif bagi perkembangan karakter siswa. Melalui metode bercerita, siswa akan menemukan banyak pelajaran yang berharga, yang dapat menjadi inspirasi dan motivasi dalam kehidupannya.

Melalui metode bercerita, siswa diajak menemukan ide atau gagasan penting dari setiap cerita yang dibacakan oleh guru. Inilah keunggulan metode bercerita yang dapat memberikan makna secara tersirat yang memberikan pesan kepada siswa. Dalam kenyataannya, memang banyak guru yang menerapkan metode tersebut dalam proses pembelajaran di madrasah. Sebagaimana yang terjadi di Madrasah Ibtidaiyah Negeri 1 Purbalingga, guru-guru di sana menerapkan metode bercerita. 
Berdasarkan hasil pra survei penelitian, memang ternyata sering digunakan metode bercerita dalam proses pembelajaran di madrasah. Siswa terlihat antusias memperhatikan dengan seksama setiap apa yang disampaikan oleh guru. Ini tentu baik bagi kelancaran dan keberhasilan proses pembelajaran. Guru bercerita dan siswa mendengarkan atau menyimak, kemudian di akhir pembelajaran mereka mendapatkan pesan dan kesan dari setiap cerita yang telah disampaikan oleh guru.

Kemudian, berdasarkan studi dokumentasi juga ditemukan bahwa rata-rata nilai prestasi hasil belajar siswa dalam kategori yang baik. Ini berarti dapat dikaitkan, antara metode bercerita dengan prestasi hasil belajar siswa. Selain itu, berdasarkan hasil observasi selama prasurvei penelitian juga ditemuakan bahwa karakter siswa baik. Ini juga dapat dikaitkan dengan metode bercerita.

Berdasarkan latar belakang masalah tersebut di atas, maka penulis tertarik untuk mengadakan penelitian mengenai hubungan metode bercerita terhadap karakter siswa di MIN 1 Purbalingga. Dengan harapan mampu mengetahui dampak dari metode bercerita dengan karakter siswa. Melalui penelitian ini, maka dapat diketahui apakah terdapat perbedaan rata-rata nilai karakter siswa antara pembelajaran yang menggunakan metode bercerita dengan pembelajaran yang tidak menggunakan metode bercerita.

\section{KAJIAN LITERATUR}

\section{Karakter Siswa}

\section{a. Pengertian Karakter}

Karakter dapat diartikan sebagai sifat manusia pada umumnya, dimana manusia mempunyai banyak sifat dan tergantung dari faktor kehidupannya sendiri. Majid berpendapat bahwa "karakter merupakanciri khas seseorang atau sekelompok orang, sifat kejiwaan, akhlak, atau budi pekerti."1 Selanjutnya, Kementerian Pendidikan dan Kebudayaan mengemukakan bahwa:

Karakter merupakan ciri khas seseorang atau sekelompok orang yang mengacu pada serangkaian sikap (attitudes), perilaku (behaviors), motivasi (motivations), dan keterampilan (skills) sebagai manifestasi dari nilai, kemampuan, kapasitas moral, dan ketegaran dalam menghadapikesulitan dan tantangan. Karakter mengandung nilai-nilai yang khas, baik (tahu nilai kebaikan, mau berbuat baik, nyata berkehidupan baik,dan berdampak baik terhadap lingkungan) yang terpateri

\footnotetext{
${ }^{1}$ Majid, A. Pendidikan Karakter dalam Perspektif Islam. (Bandung: Remaja Rosda Karya, 2010), hlm.11.
} 
dalam diridan terejawantahkan dalam perilaku. Karakter merupakan kemampuan individu untuk mengatasi keterbatasan fisiknya dan kemampuannya untuk membaktikan hidupnya pada nilai-nilai kebaikan yang bermanfaatbagi diri sendiri dan orang lain. ${ }^{2}$

"Karakter juga dapat diartikan sikap, tabiat, akhlak, kepribadian yang stabil sebagai hasil proses konsolidasi secara progresif dan dinamis". "Karakter yang kuat akan membentuk individu menjadi pelaku perubahan bagi diri sendiridan masyarakat sekitarnya". ${ }^{4}$ Karakter secara koheren memancar dari hasil olah pikir, olah hati, olah raga, serta olah rasa dan karsa seseorang atau sekelompok orang.

Zuchdi mengemukakan bahwa karakter identik dengan akhlak. Karakter merupakan nilai-nilai perilaku manusia yang universal. Karakter meliputi seluruh aktivitas manusia, baik dalam hubungannya dengan tuhan, sesama manusia, diri sendiri, maupun lingkungannya. Karakter terwujud dalam pikiran, perasaan, dan perkataan serta perilaku manusia sehari-hari. $^{5}$

Dari definisi-definisi tersebut, maka dapat disimpulkan bahwa karakter adalah sikap, tabiat, akhlak, kepribadian yang stabil dari seseorang. Karakter tidak terbentuk begitu saja, melainkan melalui proses interaksi yang terus-menerus. Karakter didasarkan pada norma-norma agama, hukum, tata krama, budaya, dan adat istiadat.

\section{b. Pendidikan Karakter}

Pada dasarnya pendidikan merupakan salah satu usaha untuk mengembangkan kemampuan yang dimilikinya baik rasa, raga, maupun pikiran dalam mencapai kehidupan yang lebih baik. Sebagaimana tercantum dalam Undang-Undang Nomor 20 Tahun 2003 tentang Sistem Pendidikan Nasional Pasal 1 ayat 1, bahwa:

Pendidikan usaha sadar dan terencana untuk mewujudkan suasana belajar dan proses kegiatan belajar mengajar supaya peserta didik dapat mengembangkan

\footnotetext{
2 Kemendikbud RI. Konsep dan Pedoman Penguatan Pendidikan Karakter Tingkat SD dan SMP. (Jakarta: Kemendikbud, 2017), hlm.17.

${ }^{3}$ Khan, Y. Pendidikan Karakter Berbasis Potensi Diri. (Yogyakarta: Pelangi Publishing, 2010), hlm.23.

${ }^{4}$ Albertus, D.K. Pendidikan Karakter Strategi Mendidik Anak di Zaman Global. (Jakarta: Grasindo, 2010), hlm.35.

${ }^{5}$ Zuchdi, D. Pendidikan Karakter: Konsep Dasar dan Implementasi di Perguruan Tinggi. (Yogyakarta: UNY Press, 2015), hlm.16.
} 
kemampuannya agar memiliki sikap spiritual, dapat mengendallikan diri berkepribadian, cerdas, berakhlak dan terampil yang bermanfaat baik bagi dirinya, keluarga, masyarakat, bangsa, dan negara. ${ }^{6}$

Mengacu pada penjelasan tentang karakter dan pendidikan di atas, maka pendidikan karakter dapat diartikan sebagai upaya sadar yang dilkukan oleh pendidik dalam rangka menanamkan nilai-nilai karakter pada peserta didik agar mereka dapat berfikir dan bertindak secara etis dalam menghadapi setiap situasi dengan memperhatikan nilai-nilai moral. Menurut Koesoema,

Pendidikan karakter adalah diberikannya tempat bagi kebebasan individu dalam menghayati nilai-nilai yang dianggap baik, luhur, dan layak diperjuangkan sebagai pedoman bertingkah laku bagi kehidupan pribadi berhadapan dengan dirinya, sesama, dan Tuhan. ${ }^{7}$

Dalam pendidikan karakter tidak sekedar mengajarkan mana yang benar dan mana yang salah kepada anak. Zuchdi mengemukakan bahwa "pendidikan karakter menanamkan kebiasaan (habituation) tentang yang baik, sehingga peserta didik paham, mampu merasakan, dan mau melakukan yang baik."8 Lebih lanjut dikemukakan bahwa: "pendidikan karakter membawa misi yang sama dengan pendidikan akhlak atau pendidikan moral."

Dari beberapa pendapat tersebut di atas, maka dapat diambil kesimpulan bahwa pendidikan karakter dilakukan untuk menanamkan nilai sosial dan spiritual yang dapat digunakan sebagai pedoman manusia dalam berinteraksi secar vertikal dan horizontal. Proses penerapan pendidikan karakter melibatkan aspek perkembangan peserta didik baik kognitif, afektif, maupun psikomotor.

\section{c. Penguatan Pendidikan Karakter (PPK)}

Penguatan Pendidikan Karakter merupakan sebuah agenda pemerintah yang saat ini gencar dilaksanakan yang bertujuan untuk memperkuat karakter. Penguatan

\footnotetext{
${ }^{6}$ Kemendikbud RI. Undang-Undang Nomor 20 Tahun 2003 Tentang Sistem Pendidikan Nasional. (Jakarta: Kemendikbud, 2013).

${ }^{7}$ Koesoema, D. Pendidikan karakter Strategi Mendidik Anak di Zaman Global. (Jakarta: PT Gramedia, 2011), hlm.5.

${ }^{8}$ Zuchdi, D., Op.Cit., hlm.17.
} 
Pendidikan Karakter dilakukan melalui proses pembentukan transformasi, transmisi, dan pengembangan potensi peserta didik dengan cara olah hati (etik dan spiritual) olah rasa (estetik), olah pikir (literasi dan numerasi), dan olah raga (kinestetik) sesuai falsafah hidup Pancasila. Untuk itu diperlukan dukungan pelibatan publik dan kerja sama antara sekolah, keluarga, dan masyarakat yang merupakan bagian dari Gerakan Nasional Revolusi Mental (GNRM).

Dalam Kemendikbud disebutkan bahwa Gerakan PPK menempatkan nilai karakter sebagai dimensi terdalam pendidikan yang membudayakan dan memperadabkan parapelaku pendidikan. ${ }^{9}$ Ada lima nilai utama karakter yang saling berkaitan membentuk jejaring nilai yang perlu dikembangkan sebagai prioritas Gerakan PPK. Kelima nilai utama karakter bangsa yang dimaksud yaitu: (1) religius; (2) nasionalis; (3) integritas, (4) mandiri; dan (5) gotong royong. Berikut ini penulis uraikan.

\section{1) Religius}

Nilai karakter religius mencerminkan keberimanan terhadap Tuhan yang Maha Esa yang diwujudkan dalam perilaku melaksanakan ajaran agama dan kepercayaan yang dianut, menghargai perbedaan agama, menjunjung tinggi sikap toleran terhadap pelaksanaan ibadah agama dan kepercayaan lain, hidup rukun dan damai dengan pemeluk agama lain. Nilai karakter religius ini meliputi tiga dimensi relasi sekaligus, yaitu hubungan individu dengan Tuhan, individu dengan sesama, dan individu dengan alam semesta (lingkungan). Nilai karakter religius ini ditunjukkan dalam perilaku mencintai dan menjaga keutuhan ciptaan. Sub-nilai religius antara lain: cinta damai, toleransi, menghargai perbedaan agama dan kepercayaan, teguh pendirian, percaya diri, kerja sama antar pemeluk agama dan kepercayaan, antibuli dan kekerasan, persahabatan, ketulusan, tidak memaksakan kehendak, mencintai lingkungan, melindungi yang kecil dan tersisih.

2) Nasionalis

Nilai karakter nasionalis merupakan cara berpikir, bersikap, dan berbuat yang menunjukkan kesetiaan, kepedulian, dan penghargaan yang tinggi terhadap

\footnotetext{
${ }^{9}$ Kemendikbud RI., Op.Cit., hlm.8.
} 
bahasa, lingkungan fisik, sosial, budaya, ekonomi, dan politik bangsa, menempatkan kepentingan bangsa dan negara di atas kepentingan diri dan kelompoknya. Sub-nilai nasionalis antara lain apresiasi budaya bangsa sendiri, menjaga kekayaan budaya bangsa,rela berkorban, unggul, dan berprestasi, cinta tanah air, menjaga lingkungan,taat hukum, disiplin, menghormati keragaman budaya, suku,dan agama.

3) Integritas

Nilai karakter integritas merupakan nilai yang mendasari perilaku yang didasarkan pada upaya menjadikan dirinya sebagai orang yang selalu dapat dipercaya dalam perkataan, tindakan, dan pekerjaan, memiliki komitmen dan kesetiaan pada nilai-nilai kemanusiaan dan moral (integritas moral). Karakter integritas meliputi sikap tanggung jawab sebagai warga negara, aktif terlibat dalam kehidupan sosial, melalui konsistensi tindakan dan perkataan yang berdasarkan kebenaran. Sub-nilai integritas antara lain kejujuran, cinta pada kebenaran, setia, komitmen moral, anti korupsi, keadilan, tanggungjawab, keteladanan, dan menghargai martabat individu (terutama penyandang disabilitas). 4) Mandiri

Nilai karakter mandiri adalah perilaku tidak bergantung pada orang lain dan menggunakan tenaga, pikiran, waktu untuk merealisasikan harapan, mimpi dan cita-cita. Sub-nilai mandiri antara lain etos kerja (kerja keras), tangguh tahan banting, daya juang, profesional, kreatif, keberanian, dan menjadi pembelajar sepanjang hayat.

\section{5) Gotong Royong}

Nilai karakter gotong royong mencerminkan tindakan menghargai semangat kerja sama dan bahu membahu menyelesaikan persoalan bersama, menjalin komunikasi dan persahabatan, memberi bantuan/ pertolongan pada orang-orang yang membutuhkan. Sub-nilai gotong royong antara lain: menghargai, kerja sama, inklusif, komitmen atas keputusan bersama, musyawarah mufakat, tolongmenolong, solidaritas, empati, anti diskriminasi, anti kekerasan, dan sikap kerelawanan. 
Mengingat pentingnya pendidikan karakter, maka perlu senantiasa dilakukan upaya penguatan. Dalam Kemendikbud disebutkan bahwa strategi implementasi PPK di satuan pendidikan dapat dilakukan melalui kegiatan: (1) intrakurikuler; (2) kokurikuler; dan (3) ekstrakurikuler. ${ }^{10}$ Penguatan Pendidikan Karakter (PPK) perlu senantiasa dikembangkan dan dibina. Peran agama dan lingkungan juga sangat mendukung keberhasilan pendidikan karakter.

Kirschenbaum mengemukakan bahwa untuk dapat meningkatkan nilai dan moralitas (karakter/akhlak mulia) pada siswa, maka sekolah dapat: (1) menanamkan nilai-nilai dan moralitas; (2) memberikan model nilai-nilai dan moralitas; (3) memfasilitasi nilai-nilai dan moralitas; (4) memberikan keterampilan untuk pengembangan nilai dan literasi moral; dan (5) mengembangkan program pendidikan nilai. ${ }^{11}$

Untuk bisa menguatkan pendidikan karakter, maka semua guru harus meningkatkan kualitas pembelajaran di sekolah. Wiyani mengemukakan bahwa salah satu upaya yang bisa dilakukan sekolah dalam upaya penguatan pendidikan karakter adalah pembinaan karakter siswa. Proses pembelajaran di kelas perlu menanamkan, pembiasaan, dan pengkondisin nilai-nilai dan moralitas. Selain itu, membangun lingkungan sekolah yang kondusif juga penting. ${ }^{12}$

Dengan demikian, berdasarkan pendapat di atas, maka dapat diketahui bahwa pendidikan karakter sangat penting. Pendidikan karakter terintegrasi dalam pembelajaran dan pengembangan budaya di sekolah. Nilai utama karakter bangsa yang perlu dikuatkan pada siswa di sekolah yaitu: (1) religius; (2) nasionalis; (3) integritas; (4) mandiri; dan (5) gotong royong. Melalui pendidikan karakter, siswa akan memiliki karakter yang baik dalam kehidupan sehari-hari sesuai norma-norma agama, hukum, tata krama, budaya, dan adat istiadat.

\footnotetext{
${ }^{10} \mathrm{Ibid}, \mathrm{hlm} .18$.

${ }^{11}$ Zuchdi, D., Op.Cit., hlm.24.

12 Wiyani, N.A. Pendidikan Karakter Berbasis Total Quality Management: Konsep \& Aplikasi di Sekolah. (Yogyakarta: Ar-Ruzz Media, 2018), hlm.109.
} 


\section{Metode Bercerita}

\section{a. Pengertian Metode Bercerita}

Metode berasal dari bahasa Yunani "Methodos", yaitu cara atau jalan yang ditempuh. Metode diperlukan dalam proses belajar mengajar. Metode sangat penting dalam pendidikan untuk memudahkan siswa dalam menangkap materi pembelajaran. Eliyanto mengemukakan bahwa "penggunaan metode yang tepat akan turut menentukan kelancaran, efektivitas, dan efisiensi proses pembelajaran." 13 Banyak sekali metode yang dapat digunakan oleh guru, antara lain metode bercerita.

Metode bercerita termasuk metode ceramah, yaitu suatu metode yang dilakukan oleh guru dengan menyajikan bahan melalui penuturan atau penjelasan lisan secara langsung terhadap peserta didik. ${ }^{14}$ Metode bercerita umum digunakan dalam proses pembelajaran di sekolah.

Metode bercerita lebih banyak menuntut keaktifan guru untuk menyampaikan informasi secara lisan kepada siswa. Menurut Umar "cerita atau kisah mempunyai fungsi edukatif yang tidak dapat diganti dengan bentuk penyampaian lain dari bahasa." 15 Lebih lanjut dikemukakan juga bahwa metode bercerita memiliki keistimewaan yang membuatnya mempunyai efek psikologis dan edukatif bagi siswa.

Berdasarkan beberapa pendapat di atas, maka dapat disimpulkan bahwa metode bercerita yaitu suatu metode yang dilakukan oleh guru untuk memperkenalkan ataupun memberikan keterangan hal baru pada anak dengan cara bertutur kata atau menyampaikan suatu cerita atau memberikan penjelasan kepada anak secara lisan. Melalui bercerita, guru berupaya untuk memberi pengalaman belajar kepada siswa. Melalui cerita yang disampaikan oleh guru, tersingkap suatu pesan, nasihat, dan informasi yang dapat ditangkap atau dipahami oleh siswa.

\footnotetext{
${ }^{13}$ Eliyanto. Ilmu Pendidikan Islam. (Kebumen: IAINU Kebumen, 2019), hlm.47.

14 Mulyasa, E. Menjadi Guru Profesional: Menciptakan Pembelajaran Kreatf dan Menyenangkan. (Bandung: Remaja Rosdakarya Offset, 2011), hlm.114.

${ }^{15}$ Umar, B. Ilmu Pendidikan Islam. (Jakarta: Amzah, 2010), hlm.190.
} 


\section{b. Pentingnya Metode Bercerita}

Metode bercerita berfungsi untuk menjadikan suasana belajar menyenangkan, memberi dorongan dan motivasi sehingga pelajaran atau materi pendidikan itu dapat dengan mudah dipahami oleh siswa. Melalui metode bercerita, proses pembelajaran tidak monoton. "Melalui metode bercerita, guru berupaya menyampaikan pesan, informasi atau cerita atau dongeng kepada siswa. Cerita tersebut bisa cerita fiksi atau cerita nonfiksi". ${ }^{16}$

Melalui cerita atau karya fiksi atau nonfiksi yang baik dapat mengembangkan karakter siswa. Sebagaimana dikemukakan oleh Zuchdi, "banyak sekolah dasar yang telah menyediakan karya fiksi atau karya sastra anak-anak yang bagus dan hal ini merupakan 'jantung' dari program pendidikan karakter." ${ }^{17}$ Dengan demikian, maka dari segi psikologis, metode bercerita mengandung makna reinforcement (penguatan) kepada siswa untuk bertahan uji dalam berjuang melawan keburukan.

Metode bercerita bermanfaat bagi perkembangan anak. Madyawati berpendapat bahwa ada beberapa manfaat metode bercerita yaitu: (1) membantu pembentukan pribadi dan moral anak; (2) menyalurkan kebutuhan imajinasi dan fantasi; (3) memacu kemampuan verbal anak; (4) memberikan sejumlah pengetahuan sosial dan nilai moral keagamaan; dan (5) memberikan pengalaman belajar untuk melatih pendengarannya; (6) memberikan pengalaman belajar dengan menggunakan metode bercerita memungkinkan anak mengembangkan kemampuan kognitif, afektif, dan psikomotor; dan (7) memberikan pengalaman belajar yang unik dan menarik, serta dapat mengatakan perasaan, membangkitkan semangat dan menimbulkan keasyikan tersendiri.kegiatan bercerita memberikan daya tarik bagi anak sehingga akan menimbulkan semangat dan keasyikan dalam bercerita. ${ }^{18}$

Berdasarkan beberapa pendapat tersebut di atas, maka dapat diketahui bahwa metode bercerita memiliki fungsi penting dalam proses pembelajaran. Fungsi metode bercerita antara lain adalah sebagai berikut: (1) menanamkan nilai-nilai moral atau

\footnotetext{
${ }^{16}$ Eliyanto. Filsafat Pendidikan Islam. (Yogyakarta: Prodi MPI FITK UIN Sunan Kalijaga Yogyakarta, 2017), hlm.29.

${ }^{17}$ Zuchdi, D., Op.Cit., hlm.39.

${ }^{18}$ Madyawati, L. Strategi Pengembangan Bahasa Pada Anak. (Jakarta: Kencana, 2016), hlm.27-41.
} 
pendidikan yang baik kepada siswa; (2) mengembangkan imajinasi dan kreativitas anak; dan (3) membangkitkan rasa ingin tahu anak. Melalui cerita, siswa dapat dengan mudah meneladani hal-hal baik yang terkandung di dalam isi cerita yang telah disampaikan oleh guru.

\section{METODE PENELITIAN}

Penelitian ini menggunakan pendekatan penelitian kuantitatif. Menurut Sugiyono, penelitian kuantitatif disebut juga penelitian tradisional karena telah lama digunakan, berlandaskan pada filsafat positivisme. Metode ini disebut kuantitatif karena data penelitian berupa angka-angka dan analisis menggunakan statistik. ${ }^{19}$ Sedangkan jenis penelitian yang digunakan pada penelitian ini yaitu penelitian quasi eksperimental design atau desain eksperimen semu. Waktu penelitian adalah antara 1 Februari 2020 sampai dengan 31 Mei 2020, dan tempat penelitian adalah di MIN 1 Purbalingga, Dusun Picung, J1. Raya Krangean RT 01 RW 0`1, Kecamatan Kertanegara, Kabupaten Purbalingga, Provinsi Jawa Tengah, Kode Pos 53358, Telp. 0811-2919-809. Madrasah ini memiliki peringkat Akreditasi A.

Desain eksperimen yang digunakan dalam penelitian ini adalah "pretest-posttest control group design" atau desain kelompok prates dan pascates yang melibatkan dua kelompok. Kategori pembelajaran dibagi menjadi dua kategori yaitu kelas eksperimen melakukan kegiatan bercerita. Sedangkan kelas kontrol tidak melakukan kegiatan bercerita.

Dari kedua kategori ini akan diteliti dampak yang muncul sebagai akibat dari perlakuan pembelajaran, yaitu karakter siswa, yang meliputi aspek: religius, nasional, integitas dan gotong royong. Kontribusi dari masing-masing pembelajaran ini dianalisis melalui pengujian statistik, sehingga diperoleh kejelasan tentang pembelajaran yang paling tepat dalam mempengaruhi pengembangan karakter siswa.

Jumlah subjek penelitian ditentukan sebanyak empat kelas, yaitu kelas III A dan III B sebagai kelas eksperimen dengan jumlah siswa sebanyak 54 orang. Sedangkan kelas III C dan III D sebagai kelas kontrol dengan jumlah siswa sebanyak 55 orang. Selain itu, untuk memperoleh informasi pendukung, maka subjek dan informan

\footnotetext{
${ }^{19}$ Sugiyono. Metode Penelitian Kuantitatif, Kualitatif, dan R\&D. (Bandung: Alfabeta, 2016), hlm.7.
} 
penelitian ini yaitu orang-orang yang berhubungan dengan metode bercerita dan karakter siswa, seperti: kepala madrasah, guru kelas, staf, wali siswa, dan komite madrasah MIN 1 Purbalingga.

Penentuan subjek penelitian dilakukan dengan menggunakan teknik purposive tandom sampling, yaitu dipilih dengan pertimbangan dan tujuan tertentu. Sesuai dengan tujuan dari penelitian ini, maka subjek penelitian dikhususkan pada menganalisis Pengaruh Metode Bercerita terhadap Karakter Siswa pada Kelas III di MIN 1 Purbalingga. Pemilihan objek berdasarkan pertimbangan tempat/lokasi tersebut merupakan salah satu MIN berprestasi di Kabupaten Purbalingga.

Penyusunan instrumen dalam penelitian ini dilakukan dengan beberapa tahapan, yaitu: (1) menentukan variabel penelitian; (2) menyusun indikator variabel penelitian; (3) menyusun kisi-kisi instrumen; (4) menyusun instrumen penelitian; (5) mengkonsultasikan dengan ahli (expert judgement); (6) melakukan uji coba instrumen; dan (7) melakukan pengujian validitas dan reliabilitas instrumen.

Instrumen penelitian ini ada tiga, yaitu: (1) instrumen pedoman wawancara untuk pengambilan data metode bercerita; (2) angket atau kuesioner untuk pengambilan data karakter (PPK) siswa; dan (3) lembar observasi untuk pengambilan data karakter siswa. Selain itu, juga didukung dengan dokumentasi.

Dalam menguji keabsahan data peneliti menggunakan tehnik uji validitas dan reliabilitas data. Instrumen penelitian yang diuji validitas dan reliabilitasnya yaitu hanya instrumen Karakter Siswa (Y). Sedangkan instrumen Metode Bercerita (X) tidak dilakukan pengujian validitas dan reliabilitasnya. Hal tersebut karena instrumen penelitian tersebut bukan berbentuk angket atau kuesioner, tetapi berbentuk pedoman wawancara, sehingga untuk validitas datanya menggunakan expert judgement.

Untuk menguji validitas dan reliabilitas instrumen penelitian, maka dilakukan ujicoba butir instrumen penelitian. Ujicoba instrumen ini dilakukan kepada siswa kelas III di MI Ma'arif NU 1 Karanggambas Kecamatan Padamara Kabupaten Purbalingga. Berdasarkan data yang terkumpul dari 39 responden, maka dapat disimpulkan 19 koefisien korelasi sebagai berikut: 
Tabel 1. Hasil Analisis Validitas Instrumen Karakter Siswa (Y)

\begin{tabular}{|c|c|c|c|}
\hline \multicolumn{5}{|c|}{ Item-Total Statistics } \\
\hline No.Item & $\mathrm{r}_{\text {hitung }}$ & $\begin{array}{c}\mathrm{r}_{\text {tabel }}=0,325 \\
\alpha=0,05 ; \mathrm{n}=39 \\
\mathrm{dk}=\mathrm{n}-2=39-2=37\end{array}$ & Keputusan \\
\hline 1 & 0,765 & 0,325 & Valid \\
2 & 0,672 & 0,325 & Valid \\
3 & 0,676 & 0,325 & Valid \\
4 & 0,748 & 0,325 & Valid \\
5 & 0,804 & 0,325 & Valid \\
6 & 0,803 & 0,325 & Valid \\
7 & 0,656 & 0,325 & Valid \\
8 & 0,945 & 0,325 & Valid \\
9 & 0,739 & 0,325 & Valid \\
10 & 0,680 & 0,325 & Valid \\
11 & 0,639 & 0,325 & Valid \\
12 & 0,709 & 0,325 & Valid \\
13 & 0,586 & 0,325 & Valid \\
14 & 0,804 & 0,325 & Valid \\
15 & 0,830 & 0,325 & Valid \\
16 & 0,769 & 0,325 & Valid \\
17 & 0,639 & 0,325 & Valid \\
18 & 0,653 & 0,325 & Valid \\
19 & 0,748 & 0,325 & Valid \\
\hline
\end{tabular}

Dari uji hasil coba instrumen dengan menggunakan 19 butir pertanyaan, ternyata semua butir instrumen dinyatakan valid. Hal ini karena nilai koefisien korelasinya $>$ 0,325. Butir instrumen yang mempunyai validitas tertinggi adalah butir nomor 8 , dengan koefisien korelasi 0,945 , dan butir instrumen yang mempunyai validitas paling rendah adalah butir nomor 13, dengan koefisien korelasi 0,586. Dengan demikian, semua butir instrumen dapat dipakai untuk pengumpulan data.

Selanjutnya, untuk hasil pengujian reliabilitas instrumen karakter siswa (Y) yaitu sebagai berikut.

Tabel 2. Reliabilitas Data Instrumen Karakter Siswa (Y)

\begin{tabular}{|c|c|}
\hline Cronbach's Alpha & N of Items \\
\hline 0,957 & 19 \\
\hline
\end{tabular}


Pada tabel di atas menunjukkan hasil perhitungan reliabilitas data dengan menggunakan metode Alpha Cronbach's dengan skor 0,957. Angka 19 menginformasikan bahwa item pertanyaan/pernyataan yang diolah berjumlah 19 . Kemudian nilai 0,957 dibandingkan dengan tabel nilai $\mathrm{r}$ product moment. Dengan menggunakan distribusi tabel $\mathrm{r}$ tersebut untuk $\alpha=0,05$ dengan derajat kebebasan sebagai berikut: maka didapat nilai $=0,325$, kemudian dibandingkan dengan nilai Cronbach's Alpha sebesar 0,957. Dengan demikian, dapat diputuskan bahwa nilai alpha $0,957>0,325$, sehingga data tersebut dikatakan reliabel atau terpercaya sebagai pengumpul data dalam penelitian.

Pengumpulan data pada penelitian ini dilakukan dengan: (1) Wawancara guru tentang pembelajaran menggunakan metode bercerita; (2) Angket yang diisi oleh siswa untuk mengukur lima karakter siswa; dan (3) Observasi yang dilakukan oleh guru tentang karakter siswa.

Data penelitian akan dikumpulkan melalui pretes dan postes siswa. Sedangkan lembar observasi diisi oleh wali kelas setelah kegiatan selesai di kelas eksperimen. Hal tersebut dimaksudkan untuk melihat seberapa besar pengaruh metode bercerita terhadap karakter dan keterampilan menulis siswa. Metode analisis data dalam penelitian ini yaitu menggunakan: (1) Descriptive Statistics; (2) Test of Equality of Error Variances; dan (3) Test of Between-Subjects Effects.

\section{HASIL PENELITIAN DAN PEMBAHASAN}

\section{Descriptive Statistics}

Descriptive Statistics digunakan untuk menyajikan statistik deskriptif mengenai rata-rata (mean) karakter siswa dan keterampilan menulis narasi siswa berdasarkan variabel faktor, deviasi standar, dan jumlah data $(\mathrm{N})$.

Tabel 3. Output Between-Subjects Factors

\begin{tabular}{|cc|c|c|}
\hline & Value Label & $\mathrm{N}$ \\
\hline Kelas & 1 & Eksperimen & 54 \\
& 2 & Kontrol & 55 \\
\hline
\end{tabular}

Output di atas menyajikan tentang variabel faktor mengenai jumlah data. Untuk Kelas Eksperimen (menggunakan Metode Bercerita) jumlah datanya 54, dan untuk 
Kelas Kontrol (bukan menggunakan Metode Bercerita) jumlah datanya 55. Secara keseluruhan, jumlah data adalah 109 siswa.

Tabel 4. Output Descriptive Statistics

Dependent Variable: Karakter Siswa

\begin{tabular}{|c|c|c|c|}
\hline Kelas & Mean & Std. Deviation & $\mathrm{N}$ \\
\hline Eksperimen & 63.89 & 6.845 & 54 \\
Kontrol & 55.45 & 8.237 & 55 \\
Total & 59.63 & 8.652 & 109 \\
\hline
\end{tabular}

Output di atas menyajikan statistik deskriptif mengenai rata-rata (mean) nilai karakter siswa berdasarkan variabel faktor, deviasi standar nilai karakter, dan jumlah data $(\mathrm{N})$.

\section{Test of Equality of Error Variances}

Test of Equality of Error Variances digunakan untuk mengetahui apakah varian antar kelompok data adalah sama. Kriteria yang digunakan yaitu: jika signifikansi < 0,05, maka disimpulkan bahwa varian kelompok data adalah berbeda. Sebaliknya, jika signifikansi $>0,05$, maka disimpulkan bahwa varian kelompok adalah sama.

Tabel 5. Levene's Test of Equality of Error Variances ${ }^{a}$ Dependent Variable:Nilai

\begin{tabular}{|c|c|c|c|}
\hline $\mathrm{F}$ & $\mathrm{df} 1$ & $\mathrm{df} 2$ & Sig. \\
\hline 1.068 & 1 & 107 & .304 \\
\hline
\end{tabular}
Tests the null hypothesis that the error variance of the
dependent variable is equal across groups.
a. Design: Intercept + Kelas

Dari output di atas, dapat diketahui bahwa signifikansi sebesar 0,304. Karena signifikansi $>0,05(0,304>0,05)$, maka dapat disimpulkan bahwa varian kelompok data adalah sama.

\section{Test of Between-Subjects Effects}

Melalui Test of Between-Subjects Effects akan diketahui hasil pengujian hipotesis dengan uji F. Pengujian menggunakan taraf signifikansi 0,05. Langkah-langkah pengujiannya yaitu:

a. Merumuskan Hipotesis

1) Ho : Tidak terdapat perbedaan rata-rata nilai karakter siswa Kelas III MIN 1 Purbalingga antara menggunakan metode bercerita dan tidak menggunakan metode bercerita. 
2) Ha : Terdapat perbedaan rata-rata nilai karakter siswa Kelas III MIN 1 Perbalingga antara menggunakan metode bercerita dan tidak menggunakan metode bercerita.

b. Kriteria Pengujian

1) Jika signifikansi $>0,05$, maka Ho diterima

2) Jika signifikansi $<0,05$, maka Ho ditolak

Tabel 6. Tests of Between-Subjects Effects

Dependent Variable:Nilai

\begin{tabular}{|l|r|r|r|r|r|}
\hline Source & $\begin{array}{r}\text { Type III Sum of } \\
\text { Squares }\end{array}$ & Df & Mean Square & \multicolumn{1}{|c|}{ F } & \multicolumn{1}{|c|}{ Sig. } \\
\hline Corrected Model & 1938.351 & 1 & 1938.351 & 33.741 & .000 \\
Intercept & 388085.140 & 1 & 388085.140 & $6.755 \mathrm{E} 3$ & .000 \\
Kelas & 1938.351 & 1 & 1938.351 & 33.741 & .000 \\
Error & 6146.970 & 107 & 57.448 & & \\
Total & 395700.000 & 109 & & & \\
Corrected Total & 8085.321 & 108 & & & \\
\hline
\end{tabular}

a. $\mathrm{R}$ Squared $=, 240$ (Adjusted $\mathrm{R}$ Squared $=, 233$ )

\section{KESIMPULAN DAN SARAN}

\section{Kesimpulan}

Berdasarkan analisis data dan pembahasan yang diperoleh dalam penelitian ini, maka dapat diambil kesimpulan bahwa: Signifikansi Metode Bercerita adalah 0,000. Karena signifikansi $<0,05(0,000<0,05)$, maka Ho ditolak. Jadi, dapat disimpulkan bahwa terdapat perbedaan rata-rata nilai karakter siswa antara pembelajaran menggunakan metode bercerita dengan pembelajaran yang tidak menggunakan metode bercerita.

\section{Saran}

Oleh karena metode bercerita memiliki korelasi dengan karakter siswa, maka guru-guru di MIN 1 Purbalingga dapat menggunakan metode tersebut dalam proses pembelajaran di madrasah. Guru perlu mencari cerita yang bagus untuk disampaikan kepada para siswa. Dengan cerita yang bagus, maka siswa akan terinspirasi dan karakternya akan semakin meningkat baik. 


\section{DAFTAR PUSTAKA}

Albertus, D.K. (2010). Pendidikan Karakter Strategi Mendidik Anak di Zaman Global. Jakarta: Grasindo.

Eliyanto. (2019). Ilmu Pendidikan Islam. Kebumen: IAINU Kebumen. . (2017). Filsafat Pendidikan Islam. Yogyakarta: Prodi MPI FITK UIN Sunan Kalijaga Yogyakarta.

Kemendikbud RI. (2017). Konsep dan Pedoman Penguatan Pendidikan Karakter Tingkat SD dan SMP. Jakarta: Kemendikbud.

. (2013). Undang-Undang Nomor 20 Tahun 2003 Tentang Sistem Pendidikan Nasional. Jakarta: Kemendikbud.

Khan, Y. (2010). Pendidikan Karakter Berbasis Potensi Diri. Yogyakarta: Pelangi Publishing.

Koesoema, D. (2011). Pendidikan karakter Strategi Mendidik Anak di Zaman Global. Jakarta: PT Gramedia.

Madyawati, L. (2016). Strategi Pengembangan Bahasa Pada Anak. Jakarta: Kencana.

Majid, A. (2010). Pendidikan Karakter dalam Perspektif Islam. Bandung: Remaja Rosda Karya.

Mulyasa, E. (2011). Menjadi Guru Profesional: Menciptakan Pembelajaran Kreatf dan Menyenangkan. Bandung: Remaja Rosdakarya Offset.

Sugiyono. (2016). Metode Penelitian Kuantitatif, Kualitatif, dan R\&D. Bandung: Alfabeta.

Umar, B. (2010). Ilmu Pendidikan Islam. Jakarta: Amzah.

Wiyani, N.A. (2018). Pendidikan Karakter Berbasis Total Quality Management: Konsep \& Aplikasi di Sekolah. Yogyakarta: Ar-Ruzz Media.

Zuchdi, D. (2015). Pendidikan Karakter: Konsep Dasar dan Implementasi di Perguruan Tinggi. Yogyakarta: UNY Press. 